\title{
PROFOUND CHANGES IN THE LEGAL SYSTEM: CONSTITUTIONAL COURT OF THE REPUBLIC OF MOLDOVA MADE IT POSSIBLE FOR EVERY LITIGANT TO RAISE THE EXCEPTION OF UNCONSTITUTIONALITY
}

DOI: $10.47743 /$ rdc-2016-1-0001

I dedicate this article to our good friend Rainer Arnold, Full Professor at University of Regensburg (Germany), for his invaluable contribution to the transformation of Law System in the Eastern and Middle Europe.

\section{Alexandru TĂNASE \\ President of the Constitutional Court of the Republic of Moldova}

"Justice is the specific idea of law." Gustav Radbruch, German legal scholar

(1878-1949)

\section{Abstract}

This study analyses the Judgment of the Constitutional Court of Moldova no. 2 of 9 February 2016 for the interpretation of Article 135 para. (1) letters a) and g) of the Constitution of the Republic of Moldova (exception of unconstitutionality), by which it has been decided that the right to raise the exception belongs to all courts of law, respectively to judges who belong to such courts, and the challenge regarding the constitutional review of certain rules which are to be applied in the settlement of a case shall be submitted directly to the Constitutional Court by the judges/panels of judges in the Supreme Court of Justice, courts of appeal and courts, where the case is at issue. Opening to every individual the opportunity to raise the exception of unconstitutionality, the existing mechanism for the protection of human rights has been redefined, representing the first significant step towards the introduction of an individual complaint to the Constitutional Court.

Keywords: constitutional review; exception of unconstitutionality; individual complaint to the Constitutional Court 
The exception of unconstitutionality, with all its peculiarities, represents the most spread and efficient means of indirect access of individuals to a constitutional court. In states with such a mechanism in place, most complaints pending before constitutional courts emerge from trial courts of law.

Nevertheless, in 21 years of activity of the Constitutional Court of the Republic of Moldova out of the total number of complaints only $6 \%$ were exceptions of unconstitutionality. For instance in Romania, since the Constitutional Court was established until 31 January 2016, the number of exceptions of unconstitutionality raised by trial courts constituted $98.7 \%$ out of the total of complaints lodged with the Constitutional Court of Romania ${ }^{1}$. These statistical data clearly show a persistence of certain system functioning deficiencies of the institution of the exception of unconstitutionality in the Republic of Moldova.

The issue is not a new one, as the Constitutional Court of the Republic of Moldova has been requested on numerous occasions to clarify the role of the Supreme Court of Justice when an exception of unconstitutionality is raised. The great majority of these complaints targeted mainly the same issue - possibility of trial courts to raise exceptions of unconstitutionality independently from the Supreme Court of Justice.

Article 135 para. (1) letter b) of the Constitution of the Republic of Moldova grants the Constitutional Court exclusive competence to establish the genuine and complete meaning of constitutional provisions, through textual and functional interpretation, to the extent it may be construed based on the text of the Constitution, considering the generic nature of the provisions, concrete situations the legislator could not foresee when drafting the provision, the subsequent regulations (whether related or contradictory), and the complex situations where the provision is to be applied etc.

In its previous case law ${ }^{2}$ the Court mentioned the need for an evolutionary interpretation of the Constitutional Court powers in order to enhance and extend the mechanisms employed by the Court. Any restrictive interpretation of the Supreme Law (that would limit, eliminate or reduce the powers of the Constitutional Court), would result in Court's deviation from the goal to enhance constitutional democracy, pursued by Constitution's framers themselves.

In the same context, it deems necessary to recall that a court should check on the solutions it delivered in its case law and whether these were functional or not, and if necessary, to depart from its own case law.

The world around us is changing rapidly, and the development and evolvement of our legal system mostly depends on the capacity to adapt and to react to these changes. The trial courts perceive an issue in a practical manner, less theoretically or abstract.

\footnotetext{
${ }^{1}$ https://www.ccr.ro/uploads/Statistica/2016/Activitate_ian_2016ro.pdf.

2 Judgment of the Constitutional Court of Moldova no. 9 of 14 February 2014 on the interpretation of Article 135 para. (1) letter a) of the Constitution; Judgment of the Constitutional Court of Moldova no. 32 of 29 December 2015 on constitutional review of the Decree of the President of the Republic of Moldova no. 1822-VII of 21 December 2015 on the appointment of a candidate for the office of Prime Minister.
} 
The law nowadays is completely different than one or two decades ago. Law in Europe today is what the trial courts state, and not just the legal texts. Irrespective of the formal value of the judicial precedent, it is impossible to speak about law and to understand law as such without taking into account what the courts state.

Following the case law of the Constitutional Court on this subject, we shall ascertain a very interesting evolution, from restrictive interpretation (Judgment of the Constitutional Court no. 15 of 6 May 1997 and Decision no. 186 of 26 March 2007) to evolutionary interpretation of the procedure of raising the exception of unconstitutionality (Judgment of the Constitutional Court no. 2 of 9 February 2016).

The arguments held by the Court in its case law ${ }^{3}$, according to which the right to submit applications before the Constitutional Court in order to examine an exception of unconstitutionality belongs exclusively to the Supreme Court of Justice, proved to have lack of practical support - the institution of exception of unconstitutionality remained inoperative.

The dialogue between the Constitutional Court and the Supreme Court of Justice during the years 1997-2007-2014 unequivocally reveals that both courts were aware of this problem ${ }^{4}$. Therefore, on 9 December 2015 the Supreme Court of Justice requested the Constitutional Court, by way of interpreting Article 135 para. (1) letter g) of the Constitution, to explain:

"1) Whether the Supreme Court of Justice is entitled to refuse trial courts to submit complaints to the Constitutional Court on the exception of unconstitutionality raised within judicial proceedings by these courts, taking into account the text Article 135 para. (1) letter $g$ ) of the Constitution?

2) What is the role of the Supreme Court of Justice in the procedure of submitting complaints to the Constitutional Court, in term of the right of trial courts of all levels to raise the exception of unconstitutionality?

3) Whether the trial courts are entitled to refuse parties in raising the exception of unconstitutionality?"

The following aspects can be construed from the request submitted by the Supreme Court of Justice:

- the relationship between trial courts and the litigants in terms of raising the exception of unconstitutionality;

- subjects entitled to raise the exception of unconstitutionality and to submit complaints to the Constitutional Court.

\footnotetext{
${ }^{3}$ Judgment of the Constitutional Court no. 15 of 6 May 1997 on the interpretation of Article 135 para. (1) letter g) of the Constitution of the Republic of Moldova.

${ }^{4}$ Judgment of the Constitutional Court no. 2 of 9 February 2016 on the interpretation of Article 135 para. (1) letter g) of the Constitution of the Republic of Moldova (exception of unconstitutionality) Case file no. 55b/2015, $\S 100,101,104$.
} 
Thus, in its Judgment no. 2 of 9 February 2016, by way of functional interpretation of Articles 20, 115, 116, 134 and 135 para.(1) letter a) and 135 para. (1) letter g) of the Constitution, the Constitutional Court explained the mechanism employed when raising the exception of unconstitutionality.

\section{The exception of unconstitutionality as an instrument of defending}

\section{the fundamental rights and freedoms}

The analysis of the institution of exception of unconstitutionality is inconceivable failing to understand the importance of the respect for human rights and the mechanisms used by constitutional courts to protect these rights.

The exception of unconstitutionality is the citizen's constitutional warrant meant to protect his rights and fundamental freedoms while resolving a dispute; that is why as long as being subjected to a jurisdiction, regardless of its nature, whether administrative or judicial, his right to challenge the constitutional legitimacy of the law applicable to the proceedings cannot be denied ${ }^{5}$.

Considering the subsidiary nature of ECHR mechanisms, the issue of individual access to the constitutional court is for a long time outside the theoretical or hypothetical areas. Stemming from the commitments deriving from the process of streamlining the ECtHR, acknowledged within the Conferences held in Interlaken (18-19 February 2010), Izmir (26-27 April 2011) and Brighton (19 to 20 April 2012), the Republic of Moldova is compelled to extend, at the national level, human rights protection mechanisms.

In this context the control undertaken through the exception of unconstitutionality shall comply with ECtHR case law stating that a Constitutional Court shall enjoy the power to repair all the encountered violations by annulling controversial regulations ${ }^{6}$.

Given the right of the individuals to access the court, thus ensuring efficient and effective protection of fundamental rights, the institution of constitutional justice succeeded to grant citizens the feeling that their rights could have been materialized?

The legislation of the Republic of Moldova does not provide for direct individual access to the jurisdiction of the Constitutional Court by way of individual complaint. Article 135 para. (1) letter g) of the Constitution of the Republic of Moldova regulates the competence of the Constitutional Court to solve the exceptions of unconstitutionality of legal acts, upon referral by the Supreme Court of Justice.

Absence of the individual complaint interconnected with an extremely restrictive interpretation of the procedure of raising the exception of unconstitutionality was

\footnotetext{
${ }^{5}$ H. Crișan, Procedure to raise the exception of unconstitutionality, in Fiat Iustitia no. 2/2011.

${ }^{6}$ S. de la Rosa, Droit constitutionnel et CEDH, PUF, 2009/5, no. 80, p. 819.

7 G. Kucsko-Stadlmayer, Les recours individuels devant la Cour constitutionnelle en droit constitutionnel autrichien, in Les Cahiers du Conseil Constitutionnel, 2001, nr. 10, Dalloz, p. 89.
}

CONSTITUTIONAL LAW REVIEW 
always ascertained as a shortcoming ${ }^{8}$ in the context of the review of constitutionality of laws, in terms of the right of individuals to defend their rights and freedoms guaranteed by the Constitution, by means of removing the application of a regulation that is contrary to the Constitution.

This indirect way allowing citizens to access the constitutional justice also offers the Constitutional Court the possibility, as guarantor of the supremacy of the Constitution, to exercise control over the legislative power in terms of respecting fundamental rights and freedoms.

\section{Exception of unconstitutionality as a way of indirect access}

\section{of individuals to the constitutional court}

The term "exception" originates from the fact that normative acts of public authorities enjoy a presumption of constitutionality, while allegations of the parties in judicial proceedings or the uncertainties of the judge on their unconstitutionality represents an exceptional situation. Thus, the exception of unconstitutionality is a procedural action of defence, by means of which the Constitutional Court is requested to state on the inconsistency with the Constitution of the provisions applicable in the case pending before the trial court ${ }^{9}$.

Stemming from the fact that the provision challenged by means of exception of unconstitutionality is subject to constitutional control as applied within a specific case pending before the trial court, the procedure of solving the exception of unconstitutionality represents a substantive control of constitutionality.

The reasoning of establishing this control is based on censorship and interference, on the part of the constitutional court, in the process of applying, by a trial court of a provision in which respect there exists a doubt of constitutionality. Otherwise, given the remedy of constitutional complaint the individual might request, apart from legal protection granted through ordinary jurisdiction, respect for his/her fundamental rights in the field of constitutional law. In this regard constitutional complaint has a double function - legal protection of the individual and protection of the objective constitutional right, thus exceeding the effects of "res judecata" only among the parties to the trial ${ }^{10}$.

In this context, it is necessary to emphasize a very important ascertainment made by the Court in its Judgment no. 2 of 9 February 2016. Stemming from the nature of the

\footnotetext{
${ }^{8}$ The study on "Strengthening the role of the Constitutional Court of the Republic of Moldova", 2015.

${ }^{9}$ Judgment of the Constitutional Court no. 2 of 9 February 2016 on the interpretation of Article 135 para. (1) letter g) of the Constitution of the Republic of Moldova (exception of unconstitutionality), §71.

${ }^{10}$ A. Dittmann, Le recours constitutionnel en droit allemande, in Les Cahiers du Conseil Constitutionnel, 2001, no. 10, Dalloz, p. 72.
} 
exception of unconstitutionality, the Court held that it can be raised not only in relation to existing acts, provided in Article 135 para. (1) letter a) of the Constitution, but also with regard to acts that are no longer in force, if under the provisions of these acts there had emerged legal relationships which continue to remain effective while the provision is applicable to the disputed legal relationships and is decisive for the resolution of the case ${ }^{11}$.

To shatter any doubt regarding the scope of application of the notion of "exception of unconstitutionality", the Court held that "the constitutionality of a law, of a provision of another normative act that shall be applicable to the parties, may be invoked only in case of a pending litigation, therefore always by way of exception and never by action".

\section{Exception of unconstitutionality as an element of a fair trial}

No law may restrict access to justice. Under Article 20 of the Constitution, any individual is entitled to effective satisfaction from the part of competent trial courts against actions infringing upon his/her legitimate rights, freedoms and interests. Failure to have an effective access to a court, the rights granted to individuals are illusory. Thus, the right to access to justice is perceived as a right to substantive and effective access, implying that the litigants shall benefit from clear and substantive possibility to challenge an act that represents a violation of his rights.

In order to guarantee effective protection of human rights, it is not sufficient to enshrine substantive rights and to specify in a constitutional way the minimum requirements for carrying out fair justice; it is also necessary to establish some procedural safeguards aimed at consolidating the functionality of these mechanisms. By way of these procedural safeguards the right to a fair trial shall be guaranteed, hence, in an effective and efficient manner.

The right to a fair trial implies also the presumption of conformity of interpreted normative acts applied by the trial court while carrying out justice with the constitutional provisions and international law. Therefore, the resolution of a dispute cannot involve promotion of a right by means of unconstitutional provisions.

As mentioned previously, the exception of unconstitutionality may be raised within pending judicial proceedings and only in case it may influence the outcome of the case before the trial court.

The substantive control of constitutionality by way of exception constitutes the sole instrument allowing the citizen to act in order to defend himself/herself against the legislator, in case where, by law, his/her constitutional rights are infringed upon.

In this context, the right of the citizens to access to the Constitutional Court by way of exception of unconstitutionality represents an aspect of the right to a fair trial.

\footnotetext{
${ }^{11}$ Judgment of the Constitutional Court no. 2 of 9 February 2016 on the interpretation of Article 135 para. (1) letter g) of the Constitution of the Republic of Moldova (exception of unconstitutionality), §73.
}

CONSTITUTIONAL LAW REVIEW 


\section{Trial court judge - "first constitutional judge"}

In its judgment of 9 February 2016, the Court held that the procedure of solving the exception of unconstitutionality implies two distinct stages:

1) the judicial stage, or the prior stage, consisting of raising the exception of unconstitutionality in a pending case before a trial court and adjudication by a judge on this procedural incident, which eventually is finalised with a complaint submitted to the Constitutional Court;

2) the stage of Constitutional jurisdiction itself, representing the resolution of the exception of unconstitutionality by the Constitutional Court.

At the first stage, the decisive role belongs to the ordinary judge, which ultimately decides to raise the exception of unconstitutionality. The judge can be called "first constitutional judge", revealing aspects of unconstitutionality in the law enforcement process. Recalling the famous decision Marbury v. Madison, this statement becomes more obvious. In this decision John Marshall, Chief Justice of the Supreme Court of the United States of America stated that if a law be in opposition to the Constitution, if both the law and the Constitution apply to a particular case, so that the Court must either decide that case conformably to the law, disregarding the Constitution, or conformably to the Constitution, disregarding the law, the Court must determine which of these conflicting rules governs the case ${ }^{12}$.

Therefore, once a certain doubt on the constitutionality of the challenged act is ascertained by the ordinary judge or is raised by one the parties, the judge is compelled to initiate the process of exercising the control of constitutionality.

In this respect the Court held that the exception of unconstitutionality may be raised:

- by the trial court, ex officio, which, in complying with the principle of supremacy of the Constitution, is not entitled to apply a provision in which regards there exists a doubt of constitutionality;

- by the parties to the proceedings, including their representatives, whose rights and interests may be affected by the application of unconstitutional provisions while settling the case.

\section{Procedural aspects of raising the exception of unconstitutionality}

According to the legal provisions, once the exception of unconstitutionality is accepted, the judge orders, by decision, the suspension of judicial proceedings.

Any suspension of judicial proceedings raises the question of affecting the time frames of these proceedings. Unlike other cases, the suspension of proceedings due to

12 Marbury v. Madison (1803) landmark United States Supreme Court Case.

STUDIES AND ARTICLES 


\section{Alexandru TĂNASE}

an exception of unconstitutionality requires a different approach, namely, from the perspective of balancing the celerity of proceedings and the quality of adopted judicial solutions, as well as the legal security. For these reasons, the Court considered it necessary to state clearly that "the suspension of proceedings until the Constitutional Court resolves the exception of unconstitutionality is necessary in order to exclude, when settling a case, any application of provisions contrary to the Constitution"13. This statement was made especially for the legislator, in view of the legislative regulations to be carried out.

Furthermore, the Court held that in view of assuring the celerity of proceedings, the parties must enjoy procedural possibility to challenge separately with recourse the decision of the ordinary judge on rejecting the request to raise the exception ${ }^{14}$. The Court issued an Address to the Parliament with a view to regulate the procedure of challenging such decisions (currently, the decision on refusing to raise the exception cannot be challenged separately with a recourse, it may be lodged only along with the merits of the case).

The Court held that, in the event of refusing to raise the exception of unconstitutionality and to solve the dispute without a prior settlement of the exception by the constitutional court, the ordinary judge would acquire prerogatives which are not proper to a trial court. For these reasons, the Court ruled that an ordinary judge shall not rule on the merits of the complaint or on the constitutionality of the challenged provisions, he/she shall rather limit exclusively to verify the fulfilment of the following conditions:

(1) the object of the exception falls into the category of acts provided for in Article 135 para. (1) letter a) of the Constitution;

(2) the exception is raised by a party or the representative thereof, or indicates that it is raised by the trial court ex officio;

(3) the challenged provisions shall be applied for the settlement of the case;

(4) there are no previous judgments of the Court dealing with the challenged provisions.

The Court held that the constitutionality control of challenged provisions constitutes the exclusive competence of the Constitutional Court. Therefore, ordinary judges are not entitled to refuse the parties to submit complaints to the Constitutional Court, unless the abovementioned conditions are not fulfilled. Therefore, any trial court called upon to settle a case, in the event of any doubt on the constitutionality of a legal provision, has both the power and the duty to submit a complaint to the Constitutional Court.

\footnotetext{
13 Judgment of the Constitutional Court no. 2 of 9 February 2016 on the interpretation of Article 135 para. (1) letter g) of the Constitution of the Republic of Moldova (exception of unconstitutionality), §81.

14 Ibidem, §88.
} 


\section{Equality of judges}

In order to understand the authentic meaning, which the constituent legislator provided for in Article 135 para. (1) letter g) of the Constitution, it is necessary to analyse and to point out the constitutional status of a judge.

According to Article 115 of the Constitution, justice shall be administered by the Supreme Court of Justice, courts of appeal and courts of law. Similarly, under Article 116 of the Supreme Law, judges sitting in trial courts are independent and shall abide only by the law. The independence of judges is one of the fundamental principles of organizing and carrying out justice. In applying the law, independence of judges excludes the notion of hierarchy and subordination. Having the role to settle disputes in an objective manner, according to the law, and being a power per se, judges cannot receive orders, instructions or suggestions of any kind regarding their judicial activity, neither inside nor outside the judiciary ${ }^{15}$.

In this context, the Court held that judges shall have sufficient powers and shall be able to exercise these powers in order to perform their tasks. Therefore, the provisions of Article 135 para. (1) letter a) and letter g) of the Constitution cannot be interpreted as restricting the right of other trial courts to submit complaints to the court of constitutional jurisdiction. Namely, such an interpretation guarantees the constitutional principle of independence of all judges in judicial proceedings and the supremacy of the Constitution in the defending the fundamental rights and freedoms.

In this context the Venice Commission pointed out that from the viewpoint of human rights protection, it is more expedient and efficient to give courts of all levels access to the constitutional court ${ }^{16}$.

Based on these considerations and taking into account the essence of the institution of "exception of unconstitutionality", the Court ruled that the right to raise the exception belongs to all trial courts, correspondingly, to judges within these courts, and the complaint on constitutionality control of certain provisions to be applied while settling a case shall be lodged directly before the Constitutional Court by the judges/panels of judges of the Supreme Court of Justice, courts of appeal and courts of law where these cases are pending.

Thus, in order to guarantee effective enforcement of this constitutional mechanism, the exception of unconstitutionality shall be adjudicated exclusively by the constitutional court upon referral by judges of all trial courts.

\footnotetext{
15 Ibidem, $\$ 97$.

${ }^{16}$ Study on individual access to constitutional justice - Adopted by the Venice Commission at its 85th Plenary Session of 17-18 December 2010 (CDL-AD(2010)039), §62.
} 
While concluding this article I had a certain dilemma while selecting its title. I was looking for something equally brief, and covering. Eventually I gave up this solution as there exist topics that cannot be simplified. Excessive simplification is likely to deprive the content, or as Albert Einstein used to say: "Everything should be made as simple as possible, but not simpler". I am absolutely convinced that the Judgment of the Constitutional Court no. 2 of 9 February 2016 is revolutionary and will lead to substantial changes in justice. I will futher refer to some effects which I think will arise in the short and medium term.

Actually this Judgment no. 2 of 9 February 2016 grants to the individual an efficient legal instrument that allows him/her to make the most of the rights guaranteed by the Constitution. Given the fact that this institution eliminates from the legal space provisions that are contrary to the Constitution, there will happen a cleansing of the legal order from unconstitutional provisions.

Opening to every individual that is part of judicial proceedings, the possibility to raise an exception of unconstitutionality, the existing mechanism for protection of human rights shall be redefined, and this fact represents the first significant step towards the introduction of the individual complaint before the Constitutional Court.

Apart from this important aspect, there shall be obtained a series of indirect effects far less important. Unlocking the mechanism of raising the exception of unconstitutionality shall convince the trial courts to use the text of the Constitution and the case law of the Constitutional Court, and shall urge the judges to keep at a distance, when necessary, purely positive approaches to the law and to accept the use of interpretative approaches of the law, hence the spirit of the law, and not only from certain rigid regulations applied ad litteram. Thus the legal supremacy of the Constitution within the legal internal order shall be guaranteed, putting an end to the anomaly in the judicial practice that hindered useful invocation of the Supreme provision in a procedure, when the law was providing otherwise.

Expanding the mechanism of the exception of unconstitutionality shall generate progress in protecting the rights and freedoms, without affecting the legal security. This will allow repealing of acts that re contrary to the rights and freedoms guaranteed by the Constitution in the incipient stage of examination before the trial courts, with no need to revise the final decision, as is the case when the challenged provisions are declared unconstitutional only upon the case has been settled.

The last effect (but not the least) I would like to mention is related to the depolitisation of the agenda of the Constitutional Court. In the situation when the majority of complaints pending before the Court come from the trial courts, and not from the political environment, we would witness not only the substantial depolitisation of the agenda of the Constitutional Court, rather an evolution of the case law that shall fundamentally change the nature of the Court. As the number of the exceptions of 
unconstitutionality increases, we shall observe the emergence of the case law equally useful and usable for the trial courts, which shall resize on a qualitatively new level the national mechanisms of human rights protection.

Finally, it would be the case to recall a statement made on several occasions: the development of judicial review of laws and its forms has been based mostly on the result of jurisdictional activity and not on the expression of will of the legislator. Functionality of any law institutions, including the exception of unconstitutionality, depends to the utmost extent not so much on the existing legal regulations as on the effectiveness of enforcement mechanisms. This was the reason why the Constitutional Court, by way of evolutionary interpretation of the Constitution, made possible the plenary functioning of this institution. 